\title{
Phosphorus supplementation of replacement heifers in the Northern Great Plains
}

\author{
JAMES F. KARN
}

Author is a Research Animal Scientist, USDA-Agricultural Research Service, Northern Great Plains Research Laboratory, P.O. Box 459, Mandan, N.D. 58554.

\begin{abstract}
Studies were initiated in 1980 and 1984 to compare animal performance, dietary $P$ levels, and serum mineral levels of $P$ supplemented and unsupplemented replacement beef heifers (Bos taurus). Phosphorus supplementation levels averaged $4 \mathrm{~g} \mathrm{day}^{-1}$ from 14 November 1980 and 24 January 1984, respectively, until 1 September 1980 and 15 October 1984, respectively, when supplemental $P$ was raised to $6 \mathrm{~g} \mathrm{day}^{-1}$. Heifers in both studies received mixed hay, primarily smooth bromegrass (Bromus inermis Leyss.), and rolled oats during their first winter and hay only the second winter. During the summer they grazed on native pastures which contained primarily western wheatgrass (Pascopyrum smithii (Rydb.) A. Löve), needleandthread (Stipa comata Trin. and Rupr.), green needlegrass (S. viridula Trin.), blue grama (Bouteloua gracilis (H.B.K.) Griffiths), and upland sedges (Carex spp.). Hereford and Hereford-Angus cross heifers in the first study showed no weight gain or serum $P$ response to supplemental $P$, but conception rate over the 2 studies was lower $(P<0.05)$ for the unsupplemented heifers and $75 \%$ of the open heifers occurred in the first study. Hereford-Simmental heifers used in the second study demonstrated an immediate weight gain response $(P<0.06)$ to supplemental $P$ which persisted to the end of the study in 1985, but there was only 1 open heifer in the unsupplemented group in this study, compared to 3 in the first study. Serum $P$ was higher $(P<0.06)$ for $P$ supplemented than control heifers only when they were removed from summer pasture in the second study. Diet $P\left(2.10 \mathrm{~g} \mathrm{~kg}^{-1}\right)$ for unsupplemented Hereford-Simmental heifers during the winter of 1984 was marginal, but diet $P\left(2.53 \mathrm{~g} \mathrm{~kg}^{-1}\right)$ for unsupplemented Hereford and Hereford-Angus heifers during the winter of 1980-1981 was clearly above recommended levels. Modest weight gain differences in the second study, serum $P$ data and differences in conception rate suggest that Northern Great Plains forages are marginal to deficient in $\mathbf{P}$ for replacement beef heifers, but $\mathbf{P}$ supplementation would be expected to produce small and variable benefits.
\end{abstract}

Key words: native range, forage phosphorus, extrusa

\footnotetext{
The author wishes to thank Mr. Richard Huppler for caring for the cattle and collecting Iesearch samples and Dr. Gary V. Richardson for assistance with statistical analysis.

U.S. Department of Agriculture, Agricultural Research Service, Northern Plains Area, is an equal opportunity/affirmative action employer and all agency scrvices are available without discrimination.

Manuscript accepted 4 Feb. 1995
}

Dietary phosphorus $(\mathrm{P})$ is considered to be deficient for much of the world's grazing livestock, (Church et al. 1971); however, the response to $\mathbf{P}$ supplementation has been erratic. Northern Great Plains rangelands are largely situated on glacial till soils that are often low in $P$, consequently forage grown on these soils may also be low in P (Black 1968). Supplementation of grazing cattle with $P$ in a salt mixture provided ad libitum is a common practice; however, the amount of $P$ supplied by this procedure and it's value are uncertain. Karn (1992) reported low ad libitum $P$ consumption with no improvement in liveweight gains of either cows or calves during 3 summer grazing periods. Judkins et al. (1985) reported a response to ad libitum $P$ supplementation on New Mexico range only when combined with drought. Although $P$ recommendations for all beef cattle classes have been reduced by the ARC (1980) and NRC (1984), P requirements for freeranging cattle are still unclear. Much of the early literature and some more recent reports (McDowell et al. 1983) have stressed the affect of $P$ supplementation on reproduction. However, Gartner et al. (1980) reported that under practical conditions other nutrient deficiencies such as protein and possibly energy supersede $\mathrm{P}$ as the first limiting factor in reproduction. There is a paucity of literature with regard to the effect of $P$ supplementation on the performance of replacement heifers grazing rangelands. Call et al. (1978) reported no liveweight gain differences in Hereford heifers over a 15 month period, where dietary $P$ levels of 1.4 and $3.6 \mathrm{~g} \mathrm{~kg}^{-1}$ on an "as fed" basis were compared. Gartner et al. (1982) reported that it took 19 months before any adverse effect was observed on feed intake or liveweight gains of beef heifers on a diet containing $0.9 \mathrm{~g} \mathrm{~kg}^{-1} \mathrm{P}$.

The objectives of this research were to determine the effect of force feeding supplemental $P$ with ground oats, on the performance of replacement beef heifer calves from weaning until just prior to their first calf, and to determine the adequacy of unsupplemented diet $\mathrm{P}$ levels compared to NRC (1984) recommendations.

\section{Materials and Methods}

Phosphorus supplementation studies with replacement beef heifers were initiated on 14 November 1980 and 24 January 1984. Fifty-three Hereford and Hereford-Angus crossbred heifer calves were used in the first study and 55 Hereford-Simmental heifer calves were used in the second study. Heifers were weighed following an over night stand without feed or water. 
After weighing, heifers were randomly assigned into 2 groups, based on weight and breeding in the first study and weight in the second study. Breeding was not used as a sorting criteria in the second study because heifers were more genetically similar. Heifers were group supplemented. One group was randomly assigned to receive supplemental phosphorus and the other group was maintained as controls. The initial $\mathrm{P}$ level in both studies was $4 \mathrm{~g} \mathrm{day}^{-1}$, the level was raised to $6 \mathrm{~g} \mathrm{day}^{-1}$ on 1 September 1981 and 15 October 1984 for heifers in the first and second studies, respectively. Supplemental $P$ levels were increased to coincide with lower forage $\mathrm{P}$ levels. Phosphorus provided as monosodium phosphate was fed with $28.5 \mathrm{~g}$ day ${ }^{-3}$ each of ground oats and dried molasses, to aid consumption. Control heifers received only ground oats and dried molasses. Trace mineralized salt (Akzo Salt, Inc., Clarks Summit, $\mathrm{Pa}$ ) was available at all times. During the 1980-1981 winter feeding period, heifers were also fed $2.7 \mathrm{~kg}$ dry rolled oats, $0.10 \mathrm{~kg}$ of soybean meal and $5.9 \mathrm{~g}$ limestone per head daily. Mixed hay, primarily smooth bromegrass (Bromus inermis Leyss.), was fed free choice. During the 1984 winter feeding period, each heifer received $2.7 \mathrm{~kg}$ dry rolled oats and $0.14 \mathrm{~kg}$ soybean meal, 6 days per week and had free choice access to mixed hay, similar in botanical composition to that used in 1981. Hay consumption was recorded in 1984 only, for all heifers together. During the first winter of each study, supplements were fed at the time oats and soybean meal were fed. Heifer treatment groups in the first study were maintained in separate pens during the winter or pastures during the summer and rotated between the 2 pens or pastures every 14 days until the beginning of the second winter when they were combined into one group. From then on heifers were separated (Karn and Lorenz 1984) only during supplementation. Heifers in the second study were maintained together except when separated into groups during supplementation. Summer grazing periods began on 22 May 1981 and 25 May 1984 and ended 5 November 1981 and 6 November 1984. Two native pastures, situated side by side were 92 and 99 ha in size and were located 3 to $5 \mathrm{~km}$ from the winter feeding area. Forage species, quantity and quality were similar between the 2 pastures. In the first study $P$ supplemented heifers grazed in one pasture and controls in the other, heifers were rotated between pastures every 14 days to minimize pasture effects. During the second study heifers from both treatments were placed on one of the pastures and rotated between the 2 pastures as forage supply dictated. Pastures contained primarily western wheatgrass (Pascopyrum smithii (Rydb.) A. Löve), needleandthread (Stipa comata Trin. and Rupr.), green needlegrass ( $S$. viridula Trin.), blue grama (Bouteloua gracilis (H. B. K.) Griffiths) and upland sedges (Carex spp.). These pastures have previously been described in more detail by Karn (1992). During the summer grazing period heifers were supplemented only on Monday and Friday, but the daily allocation of supplement was not changed, it was simply combined into 3-day and 4day portions.

Heifers used in the 1980 study were mated to Longhorn bulls to facilitate calving. Beginning in mid-June, 1981 one Longhorn bull was placed in each of the 2 pastures where they remained for a 55-day breeding season. Heifers were rotated between the 2 bulls after the first 7 days, thereafter they were rotated every 14 days. Heifers in the 1984 study were maintained in a single group, with 2 Angus bulls during a 60-day breeding season, beginning in mid-June.

Jugular blood samples were taken on 14 November 1980, 22
May and 5 November 1981; and on 24 January, 14 June, and 6 November 1984. Serum was separated from the whole blood and frozen until analyzed.

Extrusa samples were collected with 3 mature esophageally fistulated steers on alternate weeks from each pasture throughout the grazing season in 1981 and with four esophageally fistulated steers on a weekly basis from the pasture being grazed in 1984 . Fistulated steers were penned off feed over night before each sampling date. Grazing selectivity did not appear to be affected by this method. Individual animal collections were mixed, subsampled and freeze dried for nitrogen and in vitro digestible organic matter (TVDOM) analysis. Extrusa subsamples for mineral analyses were squeezed to remove saliva (Hoehne et al. 1967) and oven dried at $50^{\circ} \mathrm{C}$. All extrusa samples were ground to pass a $1 \mathrm{~mm}$ screen before chemical analyses.

During the summer of 1984 fecal output was measured weekly using a 24 hour total fecal collection from 4 yearling steers fitted with fecal collection bags and grazing with the heifers. Extrusa in vitro digestible organic matter (IVDOM) was used with the fecal output data to estimate dry matter intake for the heifers. Forage intake was calculated by dividing fecal organic matter by 1 IVDOM. Collecting steers received no supplemental $P$.

\section{Chemical and statistical analysis}

Phosphorus and nitrogen $(\mathrm{N})$ in extrusa, hay, oats and soybean meal, and $P$ in serum were determined with a Technicon Autoanalyzer ${ }^{1}$ (Technicon Industrial Systems, Tarrytown, N.Y. 10591). Crude protein was determined by multiplying $N$ by 6.25 . Atomic absorption was used to determine calcium ( $\mathrm{Ca}$ ), magnesium $(\mathrm{Mg})$ and potassium $(\mathrm{K})$ in forage and $\mathrm{Ca}$ and $\mathrm{Mg}$ in serum. In vitro digestible organic matter was determined by the Tilley and Terry (1963) procedure as modified by Moore and Mott (1974).

Animal weight gains and serum data were analyzed according to a completely randomized design. It was assumed there was no method of supplementation interaction, thus animals were considered as replicates. Conception rate data were analyzed by the chisquare test. Serum $\mathrm{P}, \mathrm{Ca}$, and $\mathrm{Mg}$ were analyzed by covariance, using SAS GLM procedures (SAS Institute 1985) to correct for initial differences in element levels.

\section{Results and Discussion}

Compared to heifer requirements, hays fed were low in $\mathrm{P}$ all 4 years, but especially in 1982 and 1984 (Table 1). Hay fed in 1984 was of poor quality as indicated by low crude protein and digestibility (IVDOM) values (Table 1). Hay dry matter intake averaged $4.6 \mathrm{~kg} \mathrm{day}^{-1}$ for all heifers during the winter of 1984 and $9.6 \mathrm{~kg}$ day ${ }^{-1}$ during January and February of 1985 . Hay consumption was lower in 1984 because heifers were smaller and they were also receiving rolled oats. Rolled oats were fed only during the initial winter to ensure that heifers would reach adequate breeding size by June. The addition of rolled oats to the diet raised dietary $P$ for the unsupplemented heifers to 2.53 and $2.10 \mathrm{~g}$ $\mathrm{kg}^{-1}$ during the initial winter of the first and second studies, respectively. The NRC (1984) dietary P requirement for growing

Mention of a trade name is solely to identify materials used and does not constitute endorsement by the USDA. 
Table 1. Mean ( \pm SD), phosphorus $(\mathrm{P})$, calcium (Ca) crude protein (CP) and in vitro digestible organic matter (IVDOM) in winter feeds fed to replacement heifers.

\begin{tabular}{|c|c|c|c|c|c|}
\hline Feed & Year & $\mathbf{P}$ & $\mathrm{Ca}$ & $\mathrm{CP}$ & IVDOM \\
\hline & & \multicolumn{3}{|c|}{$\begin{array}{c}\ldots-\ldots \mathrm{kg}^{-1} \text { dry basis } \ldots \ldots \\
1980-82\end{array}$} & $\mathrm{~g} \mathrm{~kg}^{-1}$ \\
\hline Hay & 1981 & $1.3 \pm 0.3$ & $4.4 \pm 2.1$ & $84 \pm 26$ & - \\
\hline Oats & 1981 & $4.0 \pm 0.2$ & $0.6 \pm 0.1$ & $131 \pm 11$ & - \\
\hline Soybean Meal & 1981 & $7.2 \pm 0.3$ & $2.2 \pm 0.5$ & $497 \pm 23$ & - \\
\hline \multirow[t]{2}{*}{ Hay } & 1982 & $1.0 \pm 0.2$ & $4.2 \pm 1.0$ & 一 & - \\
\hline & & \multicolumn{4}{|c|}{$1984-85$} \\
\hline Hay & 1984 & $1.2 \pm 0.5$ & $3.4 \pm 0.6$ & $58 \pm 15$ & $480 \pm 31$ \\
\hline Oats & 1984 & $3.9 \pm 0.2$ & $0.9 \pm 0.1$ & $135 \pm 22$ & - \\
\hline Soybean Meal & 1984 & $6.4 \pm 0.1$ & $5.5 \pm 0.5$ & - & - \\
\hline Hay & 1985 & $1.4 \pm 0.2$ & $5.1 \pm 0.5$ & $80 \pm 10$ & $586 \pm 24$ \\
\hline
\end{tabular}

heifers ranges from 2.0 to $2.4 \mathrm{~g} \mathrm{~kg}^{-1}$ dry matter, with lighter weight animals having the highest $P$ requirement.

Extrusa samples of grazed forage contained $\mathrm{P}$ levels that were marginal to deficient (NRC 1984) for growing heifers during October and November of 1981 and September and October of 1984 (Table 2). Although extrusa samples were squeezed to remove saliva (Hoehne et al. 1967), Langlands (1966) indicated that even squeezed extrusa samples contained more $P$ than unmasticated forage. This suggests that dietary $P$ levels for unsupplemented heifers may have been even lower than indicated by extrusa samples and were likely marginal to deficient according to NRC (1984) recommendations much of the summer grazing season. Although there are problems with extrusa samples, they represent the most readily accepted method of sampling pasture forage for chemical analysis.

Average daily gains $(\mathrm{ADG})$ were not different $(P>0.06)$ between $P$ supplemented and control heifers in the first study (Table 3). However, P supplemented heifers in the second study began to show a positive response in gains (ADG) within 60 days after the study was initiated. From 24 January to 14 June, P supplemented heifers had higher $(P<0.06)$ ADG than control heifers $(0.73$ vs $0.68 \mathrm{~kg})$. Cumulative gains $(A D G)$ for the entire study period were also slightly higher $(P<0.06)$ for $\mathrm{P}$ supplemented heifers. Results of the second study do not agree with Call et al. (1978) and Gartner et al. (1982) who reported no adverse affect on the performance of heifers up to 15 and 19 months, respectively, after they had been receiving diets containing only 1.4 and 0.9
Table 2. Mean chemical composition of native pastures sampled with esophageal fistula steers (extrusa) in 1981 and 1984.

\begin{tabular}{lccllll}
\hline \hline Month & $\mathrm{P}$ & $\mathrm{Ca}$ & $\mathrm{Mg}$ & $\mathrm{K}$ & $\mathrm{CP}^{1}$ & IVDOM $^{1}$ \\
\hline & $-\ldots$ & \multicolumn{1}{c}{1981 Extrusa } & & & & \\
May & 2.43 & 3.21 & - & - & 135 & - \\
Jun. & 2.18 & 4.38 & - & - & 81 & - \\
Jul. & 2.00 & 4.86 & - & - & 78 & - \\
Aug. & 1.90 & 4.26 & - & - & 74 & - \\
Sep. & 1.92 & 3.79 & - & - & 82 & - \\
Oct. & 1.48 & 3.68 & - & - & 68 & - \\
Nov. & 1.28 & 3.30 & - & - & 56 & - \\
& & 1984 Extrusa & & & & \\
Jun. & 2.22 & 4.27 & 1.49 & 9.82 & 114 & 689 \\
Jul. & 2.18 & 5.71 & 1.65 & 9.57 & 104 & 622 \\
Aug. & 2.02 & 5.10 & 1.44 & 7.23 & 81 & 586 \\
Sep. & 1.68 & 4.05 & 1.10 & 5.48 & 66 & 589 \\
Oct. & 1.45 & 3.04 & 0.71 & 3.38 & 58 & 579 \\
\hline
\end{tabular}

${ }^{1} \mathrm{CP}=$ crude protein; IVDOM=in vitro digestible organic matter.

$\mathrm{g} \mathrm{kg}^{-1} \mathrm{P}$, respectively. Hereford heifers were used in the studies of Call et al. (1978) and Gartner et al. (1982) while HerefordSimmental cross heifers were used in our second study. Contrasting results between these 2 studies and our second study may have been due to the heifers' nutritional history, dietary $P$ availability, heifer growth potential differences (breed effect) or a combination of all 3 .

The conception rate of $\mathrm{P}$ supplemented heifers was $100.0 \%$ in both 1981 and 1984 while the conception rate of control heifers was $88.9 \%$ in 1981 and $96.3 \%$ in 1984 . Weight gain and conception rate data appear contradictory. In 1981 weight gains were not different between treatments, but 3 out of 27 control heifers failed to conceive. In 1984 weight gains were different, but only 1 control heifer out of 27 failed to conceive. For the 2 years, $P$ increased $(P<0.05)$ conception rates by an average of 7 percentage units over the controls. However, Fishwick et al. (1977) reported no adverse effects of $P$ deficiency on reproduction when cows were on green grass at the time of breeding and Call et al. (1978) reported that reproduction in Hereford cows was not adversely affected by a diet containing only $1.4 \mathrm{~g} \mathrm{~kg}^{-1} \mathrm{P}$. Early summer forage $P$ levels in our studies were well above $1.4 \mathrm{~g} \mathrm{~kg}^{-1}$, although they were only slightly above NRC (1984) recommendations (Table 2).

Serum $P$, levels for heifers in the first study were not different between treatment groups in either the early summer or fall

Table 3. Performance of phosphorus (P) supplemented and unsupplemented (control) heifers in 1981 and $1984^{1}$.

\begin{tabular}{|c|c|c|c|c|c|c|c|c|}
\hline \multirow{2}{*}{ Category } & \multicolumn{3}{|c|}{1981} & \multirow[b]{2}{*}{ SE } & \multicolumn{3}{|c|}{1984} & \multirow[b]{2}{*}{ SE } \\
\hline & Date & $\mathrm{P}$ & Control & & Date & $\mathrm{P}$ & Control & \\
\hline Length of study (day) & & 462 & 462 & & & 402 & 402 & \\
\hline Number of heifers & & 26 & 27 & & & 28 & 27 & \\
\hline Initial & 14 Nov. 80 & 193 & 195 & & $24 \mathrm{Jan} .84$ & 252 & 251 & \\
\hline Early summer & 22 May 81 & 295 & 295 & & 14 Jun. 84 & 356 & 347 & \\
\hline $\mathrm{ADG}^{2}$ & & 0.54 & 0.53 & 0.004 & & $0.73^{\mathrm{a}}$ & $0.68^{b}$ & 0.003 \\
\hline Fall & 5 Nov. 81 & 395 & 396 & & 6 Nov. 84 & 444 & 434 & \\
\hline Cumulative ADG & & 0.46 & 0.46 & 0.002 & & $0.55^{\mathrm{a}}$ & $0.52^{b}$ & 0.002 \\
\hline
\end{tabular}

${ }_{2}^{1}$ Means within a row and year with different letters differ $(P<0.06)$.

${ }^{2} \mathrm{ADG}=$ average daily gain. 
Table 4. Initial, early summer and fall serum phosphorus (P), calcium (Ca), and magnesium (Mg) levels for $\mathbf{P}$ supplemented and unsupplemented (control) heifers in 1981 and 1984.

\begin{tabular}{|c|c|c|c|c|c|c|c|c|c|c|}
\hline \multirow[b]{2}{*}{ Period } & \multicolumn{3}{|c|}{$P\left(m g\right.$ liter $\left.{ }^{-1}\right)$} & \multirow[b]{2}{*}{$S E^{1}$} & \multicolumn{3}{|c|}{$\mathrm{Ca}$ (mg liter $\left.{ }^{-1}\right)$} & \multicolumn{2}{|c|}{ Mg (mg liter $\left.{ }^{-1}\right)$} & \multirow[b]{2}{*}{$S E^{1}$} \\
\hline & Date & $\mathrm{P}$ & Control & & $\mathrm{p}$ & Control & $\mathrm{SE}^{1}$ & $\mathrm{P}$ & Control & \\
\hline & & & & & 1981 & & & & & \\
\hline Initial & 4 Nov. 80 & 82 & 78 & - & 101 & 100 & - & - & - & - \\
\hline \multirow[t]{2}{*}{ Fall } & 5 Nov. 81 & 62 & 61 & 1.9 & $127^{2}$ & $133^{2}$ & 1.5 & - & - & - \\
\hline & & & & & 1984 & & & & & \\
\hline Initial & 24 Jan. 84 & 72 & 72 & - & 102 & 106 & - & 21 & 20 & - \\
\hline
\end{tabular}

SE=Least squares mean standard error from SAS GLM.

${ }_{3}^{2}$ Least squares means within a row and element are different $(P<0.06)$.

${ }^{3}$ Least squares means within a row and element are different $(P<0.08)$.

(Table 4). In the second study, serum $P$ was lower $(P<0.08)$ for $P$ supplemented heifers in early summer and higher $(P<0.06)$ for $P$ supplemented heifers in the fall when they were removed from pasture. Mean serum $P$ levels for heifers in both treatment groups for all sampling dates were within the normal range of $40-80 \mathrm{mg}$ liter ${ }^{-1}$ reported by the NRC (1984).

Least squares adjusted serum $\mathrm{Ca}$ levels were not different $(P>0.06)$ betwecn treatment groups in the carly summer in either study, but serum $\mathrm{Ca}$ levels were greater $(P<0.06)$ for control heifers at the end of the summer grazing season in both studies. However, serum $\mathrm{Ca}$ levels in both studies were also above $90 \mathrm{mg} \mathrm{liter}^{-1}$ which Underwood (1981) suggests to be the lower normal limit for serum $\mathrm{Ca}$ in cattle. Serum $\mathrm{Mg}$ was only measured in the second study. Least squares adjusted means were not different $(P>0.06)$ between treatments at the beginning of the grazing season, but when heifers were removed from summer pastures serum $\mathrm{Mg}$ was slightly lower $(P<0.08)$ for $\mathrm{P}$ supplemented compared to control heifers.

Total dietary $\mathrm{P}$ (forage plus supplement) in Fig. 1 shows that, according to the NRC (1984), P supplemented heifers received a

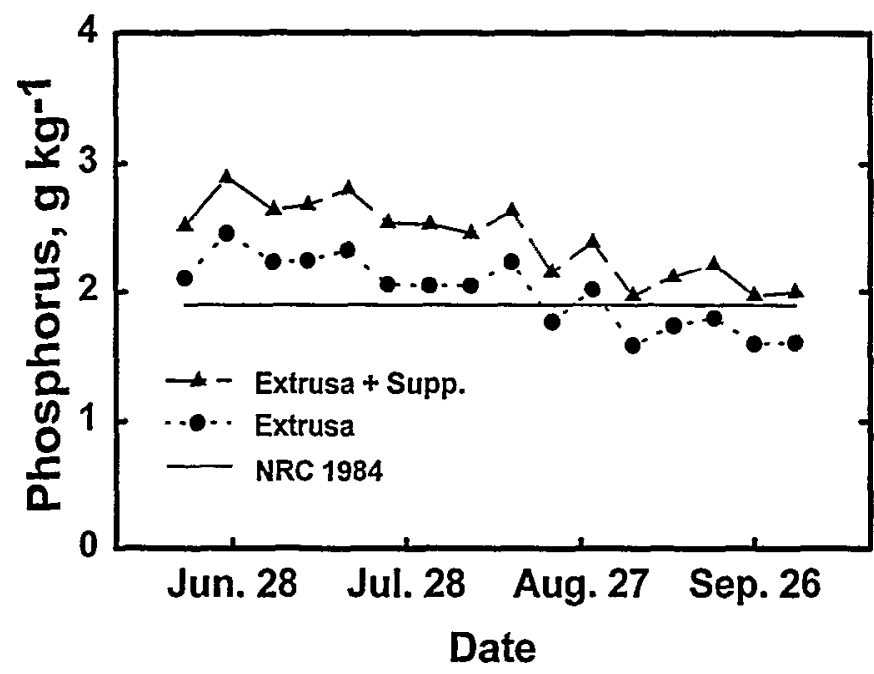

Fig. 1. Forage and total diet (forage plus supplement) phosphorus levels, based on extrusa collections during the summer of 1984 and the NRC (1984) requirement (1.9-2.0 $\left.\mathrm{g} \mathrm{kg}^{-1}\right)$ for growing heifers. diet adequate in $\mathbf{P}$ throughout the summer. However, $\mathrm{P}$ levels in extrusa samples alone indicate that control heifers were deficient in $P$ beginning about 1 September. Whether summer dietary $P$ intake levels were above or below NRC (1984) recommendations, weight gains were not increased by $\mathrm{P}$ supplementation (Table 3).

According to NRC (1984) recommendations our pastures were marginal to deficient in $\mathbf{P}$ for growing heifers during much of the grazing seasons of 1981 and 1984. However, only the HerefordSimmental heifers in 1984 exhibited a growth response to $P$ supplementation and that occurred during the wintering period when hay was fed. In contrast to the growth response to $P$ supplement in the second study, only 1 out of 27 control heifers failed to conceive while in the first study 3 out of 27 failed to conceive. Response differences between the 1981 and 1984 studies may have been due to differences in the heifers' $P$ nutrition before the studies commenced or growth potential differences between the predominantly Hereford heifers used in the first study and the Hereford-Simmental heifers used in the second study. Serum and diet $P$ levels, as well as heifer performance data all suggest that Northern Great Plains forages are marginal to deficient in $P$ for growing heifers and that a small but variable response to $P$ supplementation can be expected.

\section{Literature Cited}

ARC. 1980. The nutrient requirements of farm livestock. No. 2. Ruminants, 2nd Ed. London: Agr. Res. Counc.

Black, A. L. 1968. Nitrogen and phosphorus fertilization for production of crested wheatgrass and native grass in Northeastern Montana. Agron. J. 60:213-216.

Call, J. W., J. E. Butcher, J. T. Blake, R. A. Smart, and J. L. Shupe. 1978. Phosphorus influence on growth and reproduction of beef cattle. J. Anim. Sci. 47:216-225.

Church, D. C., G. E. Smith, J. P. Fontenot, and A. T. Ralston. 1971. Digestive physiology and nutrition of ruminants. Vol. 2 Albany Print. Co., Albany, Ore.

Gartner, R. J. W., R. W. McClean, D. A. Little, and L. Winks. 1980. Mineral deficiencies limiting production of ruminants grazing tropical pastures in Australia. Trop. Grassl. 14:266-272.

Gartner, R. J. W., G. M. Murphy, and W. A. Hoey. 1982. Effects of induced, subclinical phosphorus deficiency on feed intake and growth of beef heifers. J. Agr. Sci. (Camb.) 98:23-29.

Hoehne, O. E., D. C. Clanton, and C. L. Streeter. 1967. Chemical changes in esophageal fistula samples caused by salivary contamination and sample preparation. J. Anim. Sci. 26:626-631. 
Judkins, M. B., J. D. Wallace, E. E. Parker, and J. D. Wright. 1985. Performance and phosphorus status of range cows with and without phosphorus supplementation. J. Range Manage. 38:139-143.

Karn, J. F. 1992. Ad Libitum Phosphorus supplementation of range cows in the Northern Great Plains. J. Prod. Agr. 5:409-413.

Karn, J. F., and R. J. Lorenz. 1984. Technique to separate grazing cattle into groups for feeding. J. Range Manage. 37:565-566.

Langlands, J. P. 1966. Studies on the nutritive value of the diet selected by grazing sheep. 1. Differences in Composition between Herbage Consumed and Material Collected from Oesophageal Fistulae. Anim. Prod. 8:253-259.

McDowell, L. R., J. H. Conrad, G. L. Ellis, and J. K. Loosli. 1983. Minerals for grazing ruminants in tropical regions. Dept. of Animal Science Bull., Center for Trop. Agr., Univ. of Florida, Gainesville, and U.S. Aid.
Moore, J. E., and G. O. Mott. 1974. Recovery of residual organic matter from in vitro digestion of forages. J. Dairy Sci. 57:1258-1259.

NRC. 1984. Nutrient requirements of domestic animals. Nutrient requirements of beef cattle. Sixth Ed. Nat. Acad. Sci., Washington, DC.

SAS Institute, Inc. 1985. SAS user's guide: Statistics. SAS Inst., Inc. Cary, N.C.

Tilley, J. M. A., and R. A. Terry. 1963. A two-stage technique for the in vitro digestion of forage crops. J. Brit. Grassl. Soc. 18:104-111.

Underwood, E. J. 1981. The mineral nutrition of livestock (2nd Ed.). Common. Agr. Bur., Farnham Royal. 